\title{
Delayed diagnosis and treatment for around 20 years of an eminently treatable cause
}

\author{
Vijay Baghel, ${ }^{1}$ Garjesh Rai, ${ }^{2}$ Rakesh Biswas ${ }^{1}$
}

'Department of Medicine, People's College of Medical Sciences, Bhopal, Madhya Pradesh, India ${ }^{2}$ Department of Radiology, People's College of Medical Sciences, Bhopal, Madhya Pradesh, India

\section{Correspondence to} Professor Rakesh Biswas, rakesh7biswas@gmail.com
To cite: Baghel V, Rai G, Biswas R. BMJ Case Rep Published online: [please include Day Month Year] doi:10.1136/bcr-2012008266

\section{DESCRIPTION}

A 28-year-old Indian man presented to our emergency room with a history of fever for 1 day followed by altered sensorium and inability to speak.

Upon examination, he had a pulse rate of $56 / \mathrm{min}$, blood pressure of $60 \mathrm{~mm} \mathrm{Hg}$ systolic and temperature $95^{\circ} \mathrm{F}$. The diagnosis was apparent on a quick look at the patient (figure 1A,B). He looked very small for his stated age of 28 years and appeared more like a 3-4 year old child.

There was obvious facial puffiness and coarse facial features along with coarse skin. He had large dry lips, large thick partially visible tongue and teeth were maloccluded, along with coarse and sparse scalp hair (figure 2).

(a)

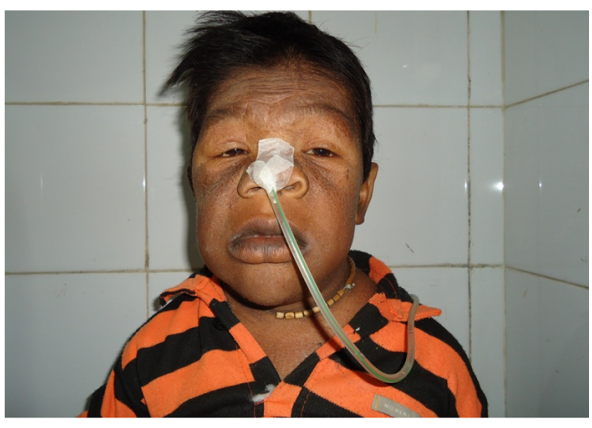

(b)

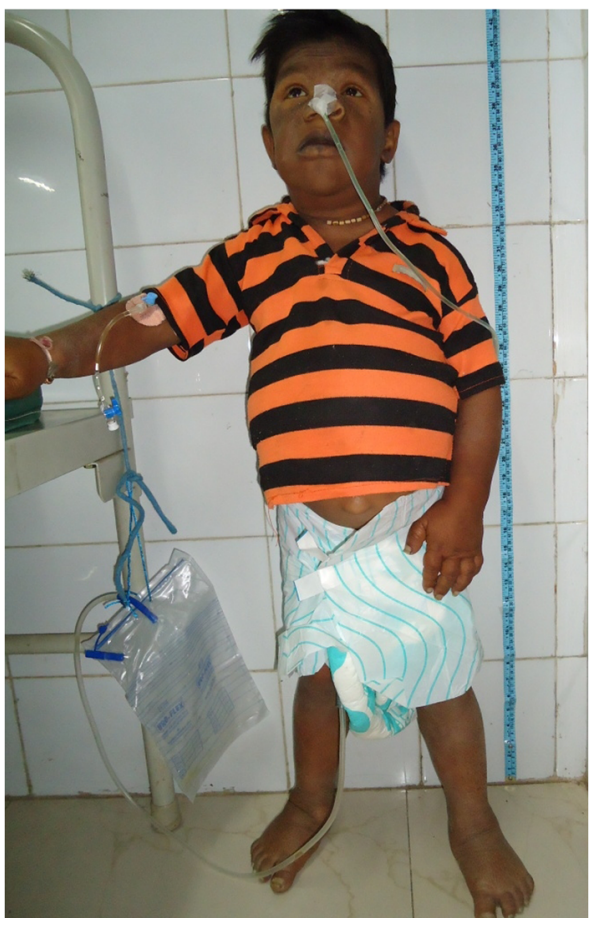

Figure $1(A, B)$ Coarse facial features with short stature.

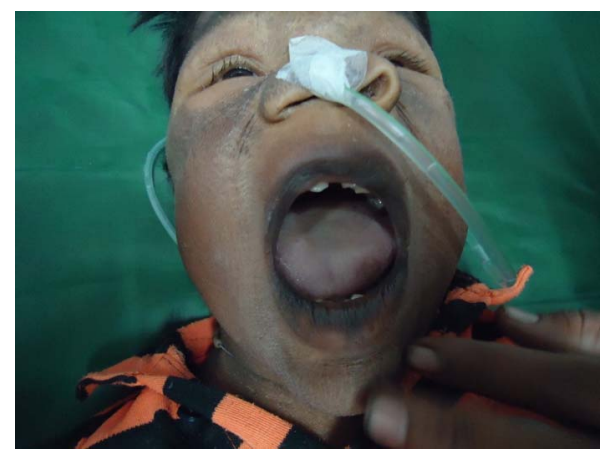

Figure 2 Maloccluded teeth.

Fingers and toes were short, and he had short arms and legs with broad oedematous hands (figure 3A,B). Neck was thick and there was no palpable goitre or thyroid nodules. Abdomen was protuberant with small umbilical hernia (figure 4). There was no organomegaly, and bowel sounds were absent.

Patient was stuporous responding to deep painful stimuli. Neck was soft, pupils were normal sized and reacting to light normally and planters were bilaterally flexor. Deep tendon reflexes showed delayed relaxation. Other examination findings were normal.

His anthropometric examination was still those of a child's proportions. Standing height $99.5 \mathrm{~cm}$, arm span $110 \mathrm{~cm}$, lower segment $50 \mathrm{~cm}$, head circumference $53 \mathrm{~cm}$ and weight was just $22.28 \mathrm{~kg}$.

(a)

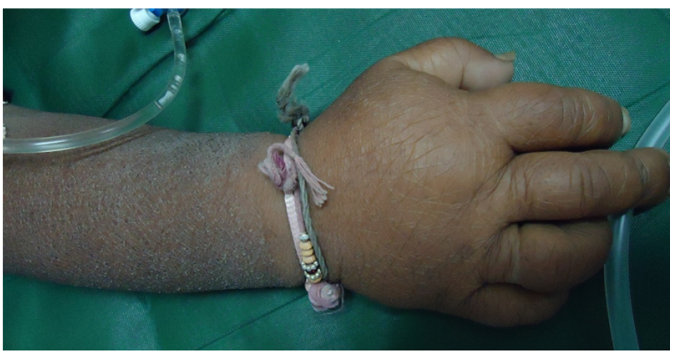

(b)

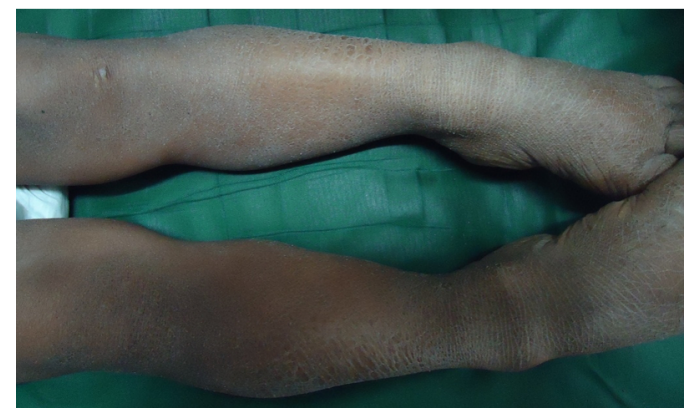

Figure $3(A, B)$ Short legs with broad oedematous hands. 


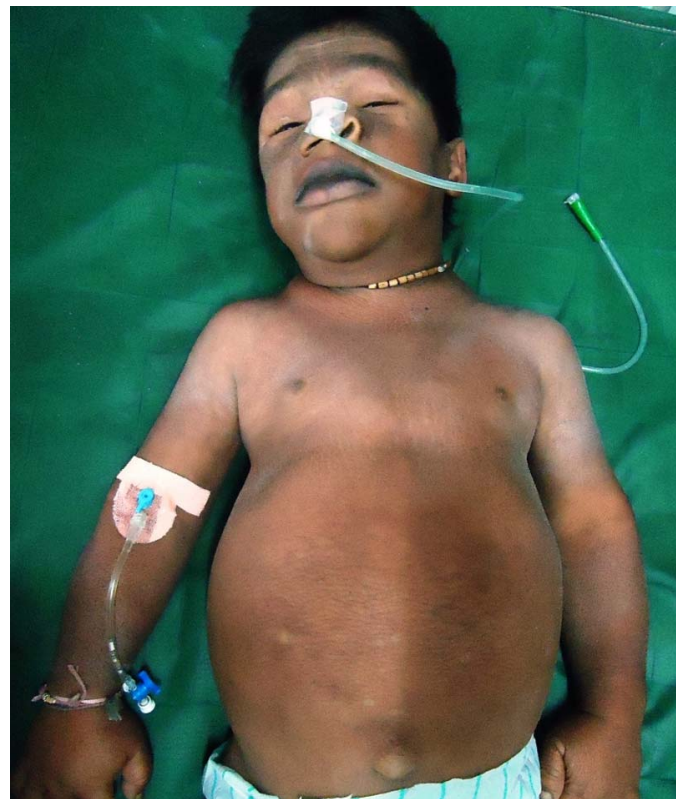

Figure 4 Protuberant abdomen with small umbilical hernia.

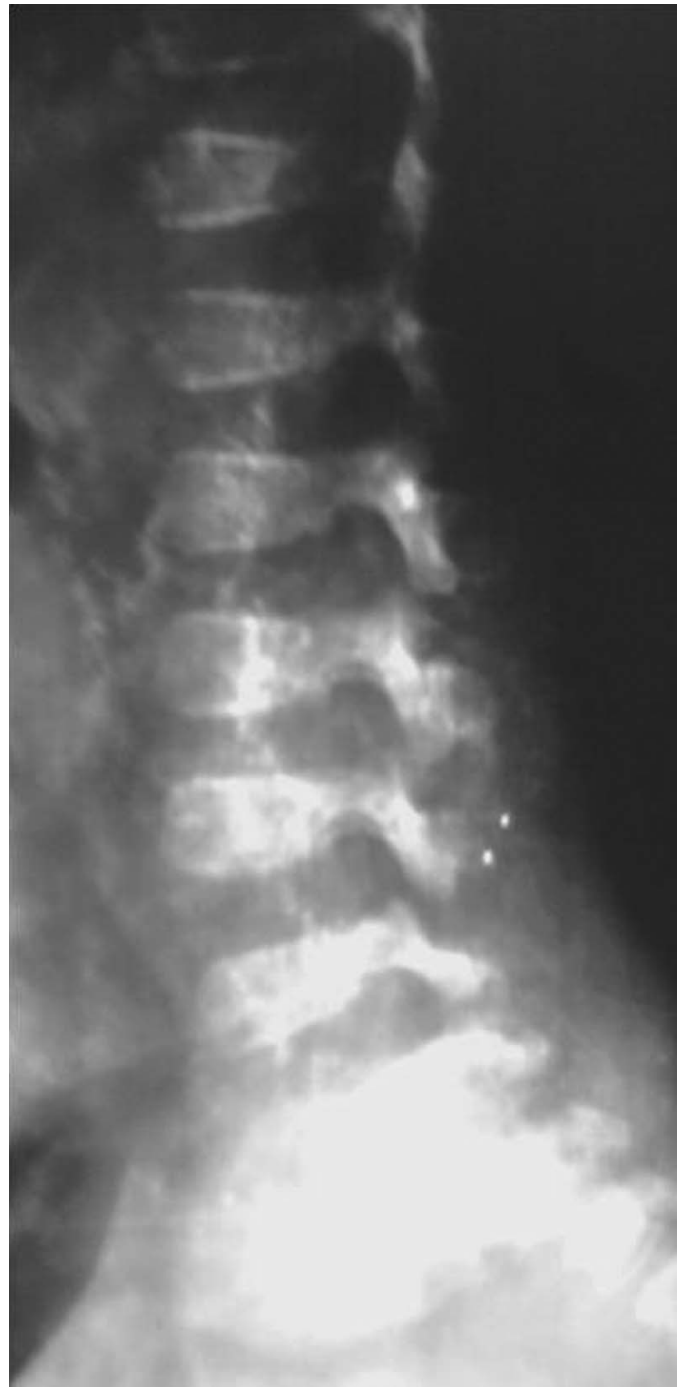

Figure 5 Anterior lipping of vertebral bodies.

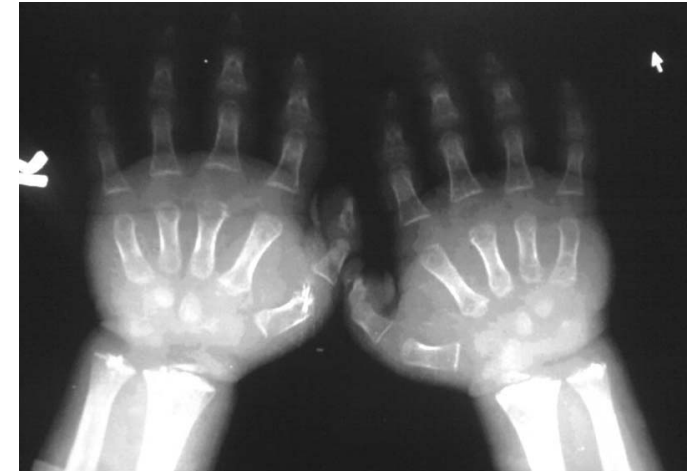

Figure 6 Small and unfused radial epiphysis and absent ulnar epiphysis.

Laboratory investigations revealed haemoglobin of $5.7 \mathrm{~g} \%$, erythrocyte seimentation rate $38 \mathrm{~mm}$ after first hour. Serum sodium $129 \mathrm{meq} / 1$, potassium $3.2 \mathrm{meq} / \mathrm{l}$. Peripheral smear for malarial parasite and malarial antigen was negative. Urine examination, liver profile, renal profile, blood sugar were within the normal limits.

His thyroid profile was suggestive of hypothyroidism: FT3 $0.54 \mathrm{pg} / \mathrm{ml}$ (normal $2.3-4.2 \mathrm{pg} / \mathrm{ml}$ ), FT4 $0.18 \mathrm{ng} / \mathrm{dl}$ (normal $7-1.51 \mathrm{ng} / \mathrm{dl}$ ) and thyroid-stimulating hormone (TSH) $281.63 \mu \mathrm{IU} / \mathrm{ml}$ (normal $0.55-4.78 \mu \mathrm{IU} / \mathrm{ml}$ ).

ECG showed low voltage, 2D Echo showed decreased ejection fraction, heart walls appeared to have myxoedematous changes. Thyroid ultrasound revealed no evidence of thyroid tissue within neck. Ultrasonography of the abdomen was normal. Fundus examination was normal. Radiological examination showed typical changes of congenital hypothyroidism with a bone age of a 1-year-old child. X-ray of lumbosacral spine showed anterior lipping of vertebral bodies (figure 5). X-ray of both hands including wrists showed short and stubby metacarpals, only two carpal bones were present with stippled calcification of growth plate in radius and ulna. Radial epiphysis was small and remained unfused (at 28 years) while ulnar epiphysis was absent (figure 6).

X-ray of both knees with an anteroposterior view showed small unfused epiphysis in femur and tibia with stippled calcification at growth plate of femur. Diffuse osteoporotic changes were also noted in visualised bones (figure 7).

X-ray of both elbows showed absent epiphysis in humerus, radius and ulna (figure 8 ). X-ray of the pelvis including both hip joints showed flattened acetabulum and absent femoral head or its epiphysis. Cortical thickening was noted at the upper end of

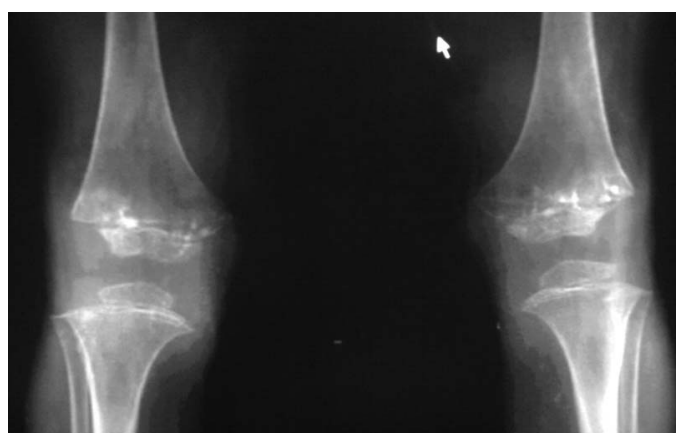

Figure 7 Small unfused epiphysis in femur and tibia with stippled calcification at growth plate of femur. 

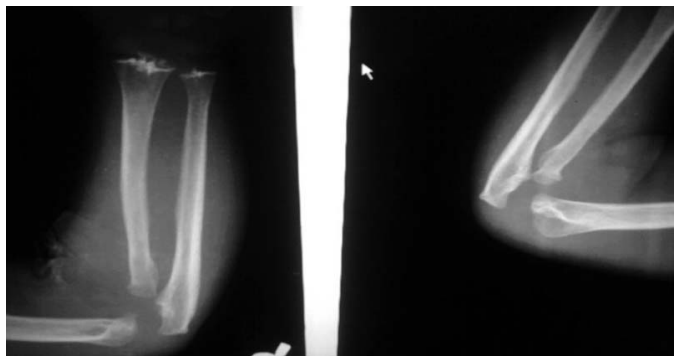

Figure 8 X-ray of both elbows showing absent epiphysis in humerus, radius and ulna.

the right femur (figure 9). CT scan of the head showed prominent cerebrospinal fluid spaces and in saggital plane showed 'J'-shaped sella and in coronal and saggital planes and at the level of pituitary fossa showed empty sella (figure 10). He was admitted to the intensive care unit and a loading dose of $500 \mu \mathrm{g}$ thyroxin given through a nasogastric tube, along with injection hydrocortisone $100 \mathrm{mg}$ intravenous 8 hourly. He was kept warm with a blanket. He responded well and gradually regained consciousness. When he became completely conscious he was put on low-dose steroids and thyroxin $100 \mu \mathrm{g} / \mathrm{day}$. Finally, he was discharged in a stable condition with the diagnosis of congenital hypothyroidism presented with myxoedema coma.

\section{DISCUSSION}

Cretinism denotes a condition of abnormal development that results from congenital hypothyroidism. Congenital hypothyroidism $(\mathrm{CH})$ is one of the most common preventable causes of mental retardation. The worldwide incidence is $1: 4000$ live births and the estimated incidence in India is $1: 2500-2800$ live births. Thyroid dysgenesis is the commonest cause accounting for $75-80 \%$ of all cases of $\mathrm{CH}^{1}{ }^{2}$

This condition is one of the most common preventable causes of gross developmental and physical delay, if undiagnosed at an early age. In later ages patient may present with slow linear growth, loss of IQ, ataxia, gross/fine motor in coordination, hypotonia and spasticity, speech disorders, attention deficit ,strabismus and sensory neural deafness.

Severe hypothyroidism requires months or years to develop; it may be because of wide variability in clinical presentation that may delay the diagnosis. ${ }^{3}$

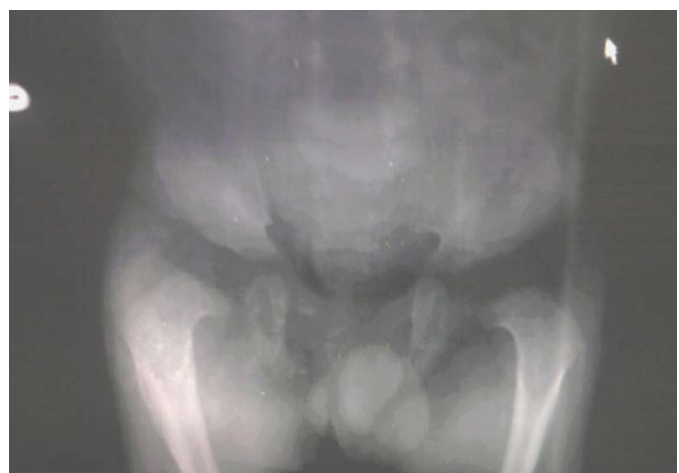

Figure 9 X-ray of the pelvis with both hip joints showing flattened acetabulum and absent femoral head or its epiphysis. (a)

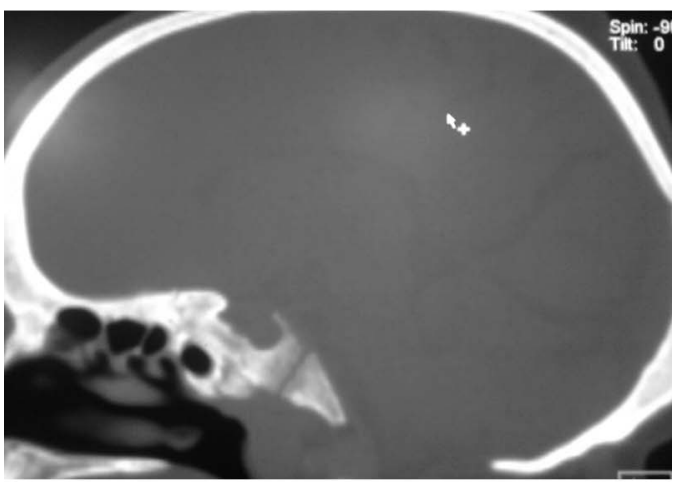

(b)

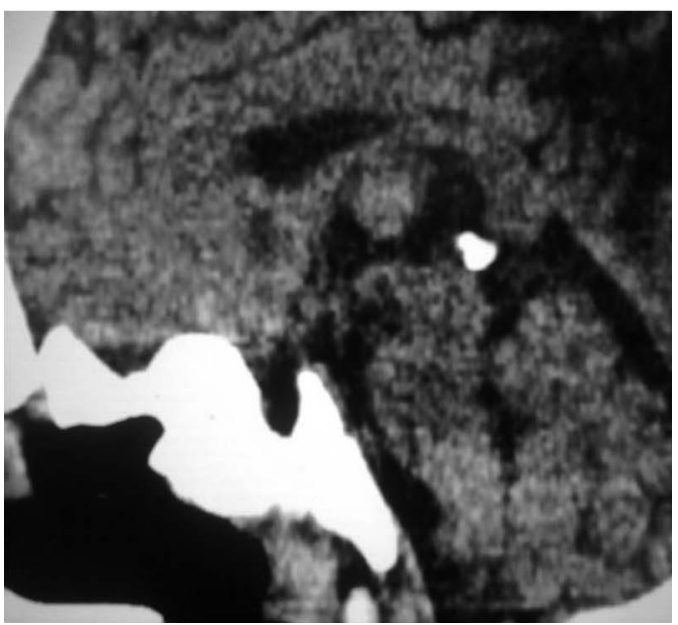

Figure 10 CT scan of the head showing prominent cerebrospinal fluid spaces and in saggital plane showing ' $J$ '-shaped sella and in coronal and saggital plane at the level of pituitary fossa showing empty sella.

This case clearly demonstrates that some patients with profound hypothyroidism may elude diagnosis for long periods of time, even under the scrutiny of multiple physicians and the multisystem manifestations of thyroid failure may be subtle in onset. This tragedy could have been prevented through implementation of TSH screening at birth, but currently it is not being done because of several factors such as cost, lack of reliable laboratories on a large scale and non-availability of baseline data in our population. ${ }^{4}$

Competing interests None.

Patient consent Obtained.

Provenance and peer review Not commissioned; externally peer reviewed.

\section{REFERENCES}

1 Desai MP, Upadhye P, Colaco MP, et al. Neonatal screening for congenital hypothyroidism using the filter paper thyroxine technique. Indian J Med Res 1994; 100:36-42.

2 Jain V, Agrawal R, Deorari A, et al. Congenital hypothyroidism AlIMS-NICU protocols 2010. [last downloaded on 8 December 2012]. http://www.newbornwhocc. org/pdf/Hypothyroidism_100810_300810.pdf.

3 Wiersinga WM. Hypothyroidism and myxedema coma. In: Degroot LJ, Jameson JL, eds. Endocrinology. 4 edn. Philadelphia: Saunders, 2001:1491-506.

4 Manglik A K, Chatterjee N, Ghosh G. Umbilical cord blood TSH Levels in term neonates: A screening tool for congenital hypothyroidism. Indian Pediatr 2005;42:1029-32. 
Copyright 2013 BMJ Publishing Group. All rights reserved. For permission to reuse any of this content visit http://group.bmj.com/group/rights-licensing/permissions.

BMJ Case Report Fellows may re-use this article for personal use and teaching without any further permission.

Become a Fellow of BMJ Case Reports today and you can:

- Submit as many cases as you like

- Enjoy fast sympathetic peer review and rapid publication of accepted articles

- Access all the published articles

- Re-use any of the published material for personal use and teaching without further permission

For information on Institutional Fellowships contact consortiasales@bmjgroup.com

Visit casereports.bmj.com for more articles like this and to become a Fellow 